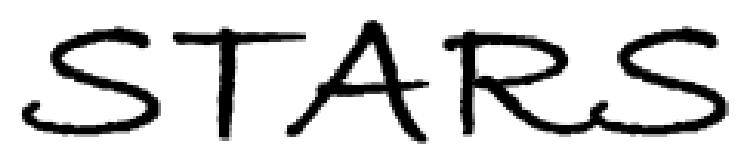

University of Central Florida

STARS

Faculty Scholarship and Creative Works

$1-13-2010$

\title{
The Value of Destination Loyalty: Myth or Reality?
}

Robertico R. Croes

University of Central Florida, robertico.croes@ucf.edu

Amir Shani

Andrew Walls

Part of the Hospitality Administration and Management Commons, and the Tourism and Travel Commons

Find similar works at: https://stars.library.ucf.edu/ucfscholar

University of Central Florida Libraries http://library.ucf.edu

This Paper is brought to you for free and open access by STARS. It has been accepted for inclusion in Faculty Scholarship and Creative Works by an authorized administrator of STARS. For more information, please contact STARS@ucf.edu.

Original Citation

Croes, R., Shani, A., Walls, A. (2010). The value of destination loyalty: Myth or reality? Journal of Hospitality Marketing and Management. 19(2), 115-136.

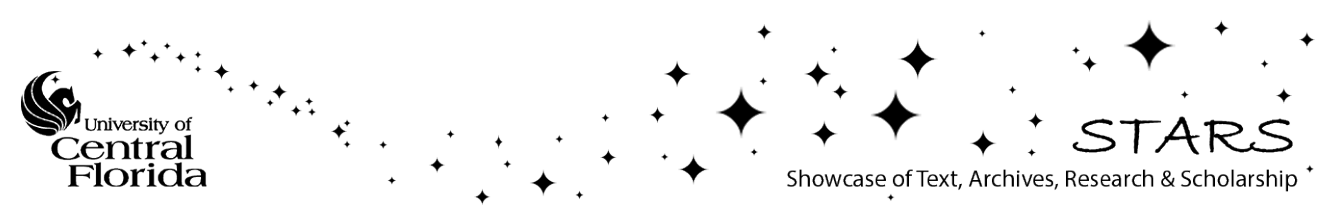


THE VALUE OF DESTINATION LOYALTY: MYTH OR REALITY?

\author{
Robertico Croes \\ Associate Professor \\ Rosen College of Hospitality Management \\ University of Central Florida \\ 9907 Universal Blvd. \\ Orlando, FL 32819 \\ E-mail: rcroes@mail.ucf.edu \\ Amir Shani \\ Doctoral Candidate \\ Rosen College of Hospitality Management \\ University of Central Florida \\ 9907 Universal Blvd. \\ Orlando, FL 32819 \\ E-mail: ashani@mail.ucf.edu \\ Andrew Walls \\ Doctoral Candidate \\ Rosen College of Hospitality Management \\ University of Central Florida \\ 9907 Universal Blvd. \\ Orlando, FL 32819 \\ E-mail: arwalls@mail.ucf.edu
}

Resubmitted for Consideration of Publication in

Journal of Hospitality Marketing \& Management

First submission: July 2008

Resubmission: October 2008 
THE VALUE OF DESTINATION LOYALTY: MYTH OR REALITY? 


\title{
THE VALUE OF DESTINATION LOYALTY: MYTH OR REALITY?
}

\begin{abstract}
Given the growing appeal of the concept of destination loyalty in tourism marketing, it is highly important to investigate the travel expenditures of loyal vs. non- or less loyal visitors. Adopting the behavioral approach to loyalty, this study examines the spending patterns of visitors to Kissimmee-St Cloud, while comparing between the different loyalty segments: no previous visit, one previous visit, and multiple visits. The analysis is based on an intercept survey conducted by the Kissimmee-St Cloud Convention and Visitors Bureau, which yielded a sample of 4,301 visitors. In contrast to the prevalent concept, the results show that first timers spend more than the more loyal segments, both in per-trip and per-day total expenditures. However, the loyalty segments are distinguished in their spending patterns at the destination, when first timers spend more on lodging, food and restaurants, and car rental, and the those with one or more previous visits spend more on gasoline, activities and entertainment, and shopping. The paper ends with an assessment of the contribution of the findings both to the literature on loyalty and to tourism destination marketers.
\end{abstract}

Keywords: Destination loyalty, Repeat visitation, Expenditures. 
The Value of Destination Loyalty 4

\section{THE VALUE OF DESTINATION LOYALTY: MYTH OR REALITY?}

\section{INTRODUCTION}

This study empirically examines the value of destination loyalty in terms of travel expenditure. Customer loyalty is one of the most prominent 'buzz' words both in contemporary marketing literature and in practice, replacing mere 'satisfaction' as the ultimate goal of service and goods organizations (Dick \& Basu, 1994; Oliver, 1999; Shoemaker \& Lewis, 1999). The growing appeal of the concept of loyalty derives from the widespread perception that loyal customers are more profitable to an organization than new customers (Reichheld \& Sasser, 1990). In addition to reduced marketing and operating costs and increased positive word-ofmouth communication, Reichheld (1996) claimed that loyal customers were also likely to pay more for a brand, a view that was widely adopted by the mainstream marketing literature (e.g., Heskett, Jones, Loveman, Sasser \& Schlesinger, 1994; Ravald \& Grönroos, 1996; Srinivasan, Anderson \& Ponnavolu, 2002). As might be understandable regarding an industry that relies heavily on marketing concepts, the belief in the value of loyal customers has also trickled into the tourism industry (Bowen \& Shoemaker, 2003; Kundampully \& Suhartano, 2000; Mattila, 2006; Tepeci, 1999). However, both in general marketing and in the tourism literature, the assumption that loyal customers are also bigger spenders than new customers, is 'common wisdom', for the most part not based on any empirical findings.

The belief in the value of loyal customers has also led firms in the tourism industry to invest enormous resources in marketing efforts, in order to retain existing customers and to encourage repeated patronage (Bolton, Kannan \& Bramlett, 2000; Dowling \& Uncles, 1997; Jang \& Mattila, 2005). Nevertheless, in the past few years scholars and researchers have begun to seriously challenge the assumption that loyal customers are more profitable than new 
customers. The limited research on this subject both in the field of general marketing (e.g., Helgesen, 2006; Ranaweera, 2007; Reinartz \& Kumar, 2000) and in the tourism literature (e.g., Oppermann, 1996; Petrick, 2004, Wang, 2004) has revealed mixed and sometimes contradicting results. Consequently, according to Niininen, Szivas and Riley (2004), the understanding of the value of loyalty in the tourism industry is still limited and deserves further research.

The current study investigates the relationship between destination loyalty and spending among visitors to Kissimmee/St Cloud, Florida. The area is one of the most important tourist destinations in Central Florida, hosting over 6 million visitors in 2004, with expenditures exceeding US\$1.3 billion dollars (Croes \& Severt, 2007). A destination was chosen for the analysis of loyalty among visitors (in contrast, for example, to hotels or cruises), since destination loyalty is a relatively new concept, which calls for further research (Pike, 2007). Specifically, studies on the usefulness of the concept of destination loyalty and its applications to tourism products or services have been particularly limited, which may have a negative impact on the understanding of loyalty as one of the major driving forces in a competitive market (Yoon \& Uysal, 2005).

For the purpose of the study, the behavioral approach to destination loyalty was adopted. This approach is not without limitations, since it does not consider the psychological attachment of the visitor to the destination, but focuses solely on the visitor's actual behavior (Petrick, 2005; Oppermann, 1997). However, as noted by Oppermann (2000), "from a practitioner point of view, the more immediate returns in term of actual visitors or customers seem more important" (p. 81). Therefore, in the current study, loyalty will be determined according to the number of recurring overnight visits to Kissimmee. 
Although spending is only one indicator for determining the profitability of visitors (in addition to marketing, operation and service costs), there are three main reasons why the study focuses on the visitors' spending behavior during their vacation in Kissimmee/St Cloud. First, customer spending is naturally a central component in determining profitability, giving an initial estimate as to the value of the customer (Niraj, Gupta \& Narasimhan, 2001; Pfeifer, Haskins \& Conroy, 2005). Second, as noted by various researchers (Jang, Bai, Hong, \& O’Leary, 2004; So \& Morrison, 2004; Soteriades \& Arvanitis, 2006), studies on travel expenditures are still limited, although spending patterns among tourists are vital for planners, marketers and business managers. Finally, exploring the differences in spending behavior between non-repeat and repeat visitors, if there are such differences, may provide a good basis for market segmentation, leading to increased revenues (Petrick \& Sirakaya, 2004; So \& Morrison, 2004).

For the reasons described above, the paper attempts to contribute to the literature on destination loyalty and on travel expenditure, two relatively understudied fields in tourism management. As more destinations aim to increase their revenue by focusing on high-spending visitors, uncovering the link between loyalty and spending might have important implications for tourism marketers, especially in their segmentation efforts. Determining the value of loyal visitors, compared to the segment of first-time visitors, is also expected to clarify whether the importance attributed to repeated visitation and the significant investments in this sector are indeed justified.

\section{LITERATURE REVIEW}

The Concept of Loyalty: Approaches and Measures 
The study of customer/brand loyalty has been attracting the attention of marketing researchers since the 1920 's, resulting in the accumulation of a substantive body of knowledge on the topic. However, there still lacks a proper definition of loyalty that will capture the wide divergence of opinions regarding the nature of customer loyalty. An early study of Jacoby and Chestnut (1978) found 53 different operational definitions of loyalty, and there is good reason to believe that today, loyalty is an even more controversial concept. Research on loyalty in the tourism industry began at the end of the 1980's, and reflected the general fuzziness with regards to the nature of the phenomenon (Oppermenn, 2000a). Nevertheless, three main approaches towards defining and measuring customer loyalty can be identified from the literature, as will be elaborated below.

The earliest studies on customer loyalty were based on consumer behavior (the behavioral approach). In its behavioral interpretation, loyalty can be defined as the act of a consumer repeatedly buying the same brand. The logic behind using repeat purchase as a determinant of loyalty is derived from the Recency-Frequency-Monetary (RFM) value paradigm, which is part of the database marketing literature (Hughes, 1995). This paradigm maintains that "clients are most likely to purchase other products offered by the company if they have recently purchased a product, if they frequently purchase products and if they purchase expensive products" (Paas, 1998: 354). Consequently, followers of the behavioral approach determine the level of consumer loyalty by measuring the sequence of purchase (how many times in a row the brand was purchased), the proportion of purchase (the rate of purchase of the brand, compared to all purchases), and/or the intensity of purchase (how often the brand was purchased within a certain purchase sequence) (Oppermann, 1997, 2000a). Other behavioral-related indicators of loyalty that are highly popular in both the general marketing and the tourism literature, are 
measuring the intentions to repurchase/revisit and the willingness to recommend the product/destination to others (e.g., Chen \& Gursoy, 2001; Kandampully \& Hu, 2007; Matzler, Füller \& Faullant, 2007; Yüksel \& Yüksel, 2007).

Nevertheless, relying solely on behavioral measures of loyalty has been under heavy criticism, the main argument being that they do not attempt to understand the causes leading to repeat/non-repeat purchase. High repeat purchase may derive from factors such as a lack of alternatives, high switching costs, or temporary convenience in using the brand, while low repeat purchase may derive from variety seeking or different usage situations (Dick \& Basu, 1994; Petrick, 2005). Therefore, alternative measures for loyalty were developed, which consider the psychological attachment of the customers to the brand by itself (the attitudinal approach), or in combination with the behavioral dimension (the composite approach). The followers of the latter advocate the perception that a truly loyal customer must both purchase the brand as well as have a positive attitude towards it (Backman \& Crompton, 1991; Oliver, 1999; Petrick, 2004;

Shoemaker \& Lewis, 1999). This integrative approach allows us to identify spurious loyalty (high repeat patronage but with a relatively negative attitude) and latent loyalty (low repeat patronage but with a relatively positive attitude), and thus offers more practical implications for marketers (Dick \& Basu, 1994).

Although the composite approach offers clear advantages as it reflects a more holistic picture of loyalty, Oppermann (1999, 2000a, 2000b) argued that loyalty research in tourism should nevertheless adopt, at least for the near future, the behavioral approach. The main reasons for this were (1) a composite measurement of loyalty has practical problems, especially since it calls for very long questionnaires; (2) attitudes tend to change over time, therefore measuring them at one point in time does not necessarily reflect the overall picture; (3) surveys which 
measure attitudes are usually conducted during or after the trip, when in fact they should be conducted before the trip; (4) actual behavior is more important for practitioners than attitudes that might or might not be translated into visits; and (5) in contrast to most products and services, vacation travel is a relatively rare purchase, and therefore is likely to reflect a conscious decision. Consequently, it is likely that actual behavior will also reflect positive attitudes towards the destination. In addition, as was noted by Pritchard, Howard and Havitz (1992), psychometrically sound instruments for measuring attitudinal loyalty are still missing in the tourism literature. Thus, in light of the present limitations of the attitudinal and the composite approaches, the current study will employ the behavioral approach to loyalty, when loyalty is measured based on the actual behavior of the visitors, i.e. prior visitations to the destination.

\section{Destination Loyalty as Repeat Visitation}

Repeat visitation is an important phenomenon, as repeat visitors account for more than half the total tourist arrivals at many destinations (Darnell \& Johnson, 2001; Niininen, et al., 2004; Wang, 2004). A wide range of studies investigate the antecedents and the factors leading visitors to repeatedly return to the same destination. The seminal work of Gitelson and Crompton (1984) on repeat visitors reveals five factors which contribute to the decision to return to a familiar destination: (1) reduced risk of a forthcoming unsatisfactory experience; (2) the assurance that the visitors will find "their kind of people" at the destination; (3) special emotional attachment to the destination; (4) the desire to experience some aspects of the destination that were omitted during previous visits; and (5) a will to expose significant others to experiences that were satisfying to the visitors. More recent studies also found that visitors often chose to return to a destination in order to establish and strengthen their interpersonal relations 
with the local people, or with fellow tourists, thus granting more meaning and a sense of authenticity to their experience (Fakeye \& Crompton, 1991; Kim \& Jamal, 2007; Levy \& Hassay, 2005; Wickens, 2004).

Although the level of satisfaction influences tourists' repeat visit intentions (Han \& Back, 2006; Kozak, Nigné \& Andreu, 2004; Lee, Graefe \& Burns, 2007), it is worth mentioning, however, that being satisfied with a destination (or with other tourism services) does not necessarily lead to repeat visitation (Chang, 2006; Kozak, 2006; Rittichainuwat, Qu \& Mongkhonvanit, 2006; Skogland \& Siguaw, 2004). Even highly satisfied visitors might choose a different destination, if they seek new experiences and novelty. Indeed, Lau and McKercher (2004) found that while repeat visitors to Hong Kong are more likely to shop or dine, first-time visitors are much more likely to travel widely throughout the region, join commercial tours and visit icon attractions. Other studies also found differences between first-time and repeat visitors with regards to their activities at the destination (Answar \& Sohail, 2004; Kemperman, Joh \& Timmermans, 2004; Oppermann, 1996, 1997; Tiefenbacher, Day \& Walton, 2000), leading to the conclusion that differentiation between them is a good basis for market segmentation. However, what remains a controversial issue is who the more valuable visitor is, from the perspective of a destination.

The Value of Loyalty: The Debate

The perception that retaining existing customers is more economically worthwhile than acquiring new customers is well accepted by researchers and practitioners from many industries, as well as the tourism industry. It has been argued that loyal customers are more profitable than new customers because (1) they are less price-sensitive, thus are ready to pay more for a brand; 
(2) since they are familiar with the service, it is less costly to serve them; (3) they represent a more stable source of revenue, reducing future marketing costs; (4) since the organization usually retains their personal details, they are more accessible for direct marketing; (5) loyalty secures the relationship between buyer and seller, making it more likely that the customer will choose the brand over competitors in the future; (6) they are expected to be more forgiving in relation to errors committed in the provision of a service, and attribute them to 'unstable factor'; and (7) they generate more positive word-of-mouth communication, which consequently brings in additional business (Bowen \& Shoemaker, 2003; Petrick, 2004; Lau \& McKercher, 2004; Mattila, 2006b; Oliver, 1999; Oppermann, 2000a; Reichheld \& Sasser, 1990; Shoemaker \& Lewis, 1999).

The perceived high value of loyal customers has led many organizations to create often expensive loyalty programs, which grant benefits and incentives to repeat customers, for the purpose of encouraging repeat patronage and establishing long-term relationships with customers (Dowling \& Uncles, 1997; Stauss, Schmidt \& Schoeler, 2005). This trend is widely adopted in the hospitality and tourism industry, including airlines, hotel chains, restaurants, casinos, cruises, and theme and amusement parks (Bai, Buxton, Sammons \& Shoemaker, 2006; Klophaus, 2005; Mattila, 2006a; Palmer \& Mahoney, 2005; Wirtz, Mattila \& Lwin, 2007). Interestingly, the concept of loyalty programs has begun to attract the attention of destination marketers as well. For example, Fyall, Callod and Edwards (2003) described the attempts to establish loyal visitor programs for Stockholm and Barbados, aimed at rewarding and encouraging repeat visitation. In any case, even without formal programs, the appeal of loyal customers (i.e. visitors) has clearly trickled into destination marketing, as more destinations adopt strategies focused on attracting visitors to return to the destination (Lehto, O'Leary \& Morrison, 2004). 
The assumption that profitability is linked to loyalty only started to be seriously challenged by marketing scholars and researchers in the past few years. A few researchers analyzed the aforementioned link, leading to conclusion that the profitability of loyal customers is a controversial matter that should not be taken for granted. Reinartz and Kumar, prominent opponents to the mass adoption of the customer loyalty concept, investigated a large retail firm (2000) and four other service providers (2002), and revealed surprising results in both studies. It was found that repeat customers are not necessarily more profitable than first-timers, since the cost of serving them is not lower and they do not pay higher prices. In the second study it was also found that the link between loyalty and positive word-of-mouth is not as strong as might be expected.

More recent studies strengthen the conclusion that the profitability of loyal customers is a contentious issue that should be further examined. To name a few examples, in Helgesen's (2006) study on fish products' exporters and their customers, a positive correlation was found between customer loyalty and customer profitability, but this link was digressive, i.e. increased customer loyalty had a positive effect on profitability, but at a decreasing rate. Ranaweera (2007), in her study of the British telecommunication sector, indicated that long-term customers are not always more profitable than new customers, leading her to conclude that "the greater profitability of the so-called 'loyal' customers appears to be overstated" (p. 119). It should be noted, however, that some studies did find a positive link between loyalty and profitability (see, for example, the studies of Loveman, 1998, and Hallowell, 1996, on the banking sector). Even assuming that loyal customers are indeed more profitable which, as can be seen, is still in dispute, Henry (2000) warned about the reliance of firms on their loyal customers, claiming that "today's customers, no matter how loyal, will someday cease to be customers" (p. 15). 
Therefore, neglecting the competition over new customers might lead to severe consequences in the long term. In addition, he called for caution when competitors' customers are presumed loyal, and firms concede potentially valuable markets without a fight.

Although most of the loyalty research in tourism has focused on examining the antecedents and the factors leading to loyalty, the underlying assumption being that it is desirable for tourism businesses (e.g., Sim, Mak \& Jones, 2006; Srinivasan, Anderson \& Ponnavolu, 2002; Yoon \& Uysal, 2005), the limited scope of this research has revealed mixed and divisive results. The most comprehensive investigation for determining the profitability of loyal visitors was carried out by Petrick (2004), who found that loyal cruise customers were more likely to visit in the future and spread positive word of mouth, but first time visitors - and less loyal visitors in general - spent more money and were less cost-sensitive. These findings led Petrick (2004) to the conclusion that "first-time visitors are a very viable market" (p. 468), and should not be neglected by cruise marketers. On the other hand, Miller and Grazer (2003) calculated and found that the loss of a very loyal cruise customer, termed "apostle" - one that sails exclusively with that cruise line, cruising at least twice a year and taking long cruises - costs the cruise line upward of $\$ 1,755,000$. Therefore, they recommend cruise lines to identify the "apostles" and handle them with special attention. However, most of the research on the value of customer loyalty in the tourism industry was conducted at the level of destination, and investigates the subject mainly from the perspective of travel expenditure.

One of the first attempts to address the issue was conducted by Oppermann (1996), who found similar expenditure patterns between first-time and repeat visitors to Rotorua, New Zealand. However, since the latter stay significantly longer than the former, their per-day spending was actually lower. In a later study, conducted among international visitors to New 
Zealand, Oppermann (1997) found similar results in general, although they varied across nationalities. In the case of visitors from the UK, Hong Kong, Germany and Canada, the repeaters were the ones who spent more, although not substantially. Consistent with Oppermann's findings, in a study among Japanese travelers to the U.S., Jang, Bai, Hong and O'Leary (2004) found that first timers spend more than repeaters in the overall sample. However, they found that high-income earners are significantly heavier spenders regardless of the number of previous visits to the destination. Different results were found by So and Morrison (2004) among visitors to Taiwan, where no significant spending differences were found between firsttime and repeat visitors, except for the U.S. segment. Lastly, in striking contrast to most of the findings described above, Wang (2004) was one of the few researchers whose findings from a study of visitors from Mainland China to Hong Kong, confirm the traditional view of loyal visitors as bigger spenders than first-time visitors. Wang (2004), therefore, in contrast to Petrick (2004) and others, concluded that that the extra attention to be paid to repeat visitors is justified.

At the very least, the mixed results on the subject, and the variations among different sectors, levels of income and nationalities, imply that the relationships between loyalty and profitability, in general, and loyalty and expenditure, in particular, are controversial and deserve further research. It is especially required in light of the increasing evidence which imply that the heavy reliance on repeat visitors on behalf of many destinations might be based on partially false assumptions, i.e. that loyal visitors tend to spend more than less or not-loyal visitors. This lack of clarity regarding the value of visitor loyalty has clear negative implications on destination marketers and their efforts to increase revenue through effective market segmentation. Therefore, this study will empirically examine the differences between different loyalty segments in regard 
to their spending patterns, taking Kissimmee-St Cloud as a case study, while assessing their value to the destination marketers.

\section{METHODOLOGY}

\section{The Destination}

Osceola County comprises the communities of Kissimmee, St Cloud, Celebration, Poinciana and Harmony, but is marketed worldwide and best known as Kissimmee-St Cloud. It is one of the fastest growing counties in the U.S., with an economy essentially based on the tourism industry. The main source of attraction to the county is its closeness to Disney World and other Central Florida attractions and theme parks. Nevertheless, Kissimmee-St Cloud in itself has a variety of shopping facilities, restaurants, museums, historic attractions, sport activities, as well as a busy nightlife to offer its guests. After a sharp decline in the number of visitors following 9/11, tourism in Kissimmee-St Cloud has been growing since 2003, with yearly visitation to the county increasing from 5.4 million visitors in 2003 to 6.3 million visitors in 2006 (Kissimmee-St Cloud Convention and Visitors Bureau, 2006).

The majority of the visitors to Kissimmee-St Cloud in 2006 came from North America (84\%), followed by Western Europe and South America (5\% each) and Mexico/Central America (4\%). It should be noted that Kissimmee-St Cloud is a classic destination for domestic tourists, when U.S. visitors to the area totaled 4.7 million in 2006 , representing $74 \%$ of the market (Kissimmee-St Cloud Convention and Visitors Bureau, 2006). A recent study found that expenditures by visitors to Kissimmee-St Cloud have a significant impact on the local economy, through the multiplier effect, that goes beyond the hospitality and tourism sectors, such as on the fields of agriculture, construction, manufacturing, educational services and health and social services (Croes \& Severt, 2007). 


\section{Sampling}

Data for this study was collected by the Kissimmee-St Cloud Convention and Visitors Bureau (KSCVB) during 2006, using a regular intercept survey among visitors to the county. Intercept surveys aim to target and interview face-to-face customers or potential customers in their natural environments, e.g., malls, restaurants and attractions - in contrast to mail or telephone interviews- and have shown to be an effective data collection method, that can provide better access to more harder-to-reach segments (Bush \& Hair, 1985; Miller, Wilder, Stillman \& Becker, 1997). Although it has clear limitations as it constitutes a form of convenience sampling, the intercept survey approach has been widely adopted in tourism and hospitality (e.g., Finn \& Erdem, 1995; Kim, Borges \& Chon, 2006; Litvin \& Kar, 2001; Pearce \& Schott, 2005), as it has been recognized as highly valuable for interviewing tourists, since it presents little potential recall bias.

In 2006, the KSCCVB administered approximately 880 intercept surveys each month from guests in lodging establishments, yielding more than 10,600 respondents over a twelvemonth period. The participants were recruited from a wide variety of hotels, motels and timeshare properties, in order to ensure maximum heterogeneity and to minimize the limitations of the intercept survey approach. Excluded from the targeted properties were campgrounds, convention hotels and on-site theme park resorts. Visitors were approached by trained interviewers and were asked to participate in the survey immediately after check-out from their respective lodgings, at different times of the day, both on weekdays and on weekends. For the purpose of the study, a visitor was defined as a person who stayed overnight in a paid 
accommodation in Osceola county, regardless of the distance traveled. Therefore, day visitors and visitors staying with friends and relatives (VFR) were also excluded from the survey.

Out of the total number of participants in the KSCVB study, only 4,305 of them reported their expenditures and number of previous visits, and therefore will be included in the current analysis. Four respondents reported on lodging, Shopping, gasoline, or car rental expenditures that were deemed extreme and not proportional (might due to data input error), and therefore excluded from the analysis, leaving sample of 4,301 participants. Out of those $71.7 \%$ were domestic US visitors, while the rest, 28.3\%, were inbound tourists (including Canadian tourists, who formed the largest group, with 263 visitors). Sixteen percent were under the age of 29 , $61.5 \%$ were between the ages of 30 and 49 , and the remainder of the sample were aged 50 and above. Regarding the participants' annual income, $44.3 \%$ earn less than $\$ 60,000$ and $43.5 \%$ earn $\$ 60,000$ or more, while the remainder refused to answer that question.

\section{Instrument/measures}

The questionnaire was composed of thirty-seven questions divided into 14 sections, including three which were relevant to the current study. First, questions pertaining to socioeconomic aspects related to the participants' age, annual income and country of origin. Since the vast majority of the sample comprised domestic visitors, with the remaining participants coming from a large number of countries, the visitors were divided into U.S. and non U.S visitors. Second, the participants were asked to state their expenditures in the area of Kissimmee-St Cloud, in relation to lodging, food, car rental, gasoline, activities and entertainment, and shopping. It should be noted that although the participants were also asked about their expenditures on their entire trip - which may have included other destinations - the current study 
investigates spending in Kissimmee-St Cloud only. While studies on travel expenditures usually involve the risk of recall bias (Mok \& Iverson, 2000; Wang, Rompf, Severt \& Peerapatdit, 2006), the accuracy of the visitors' spending estimated in this study is expected to be high since the surveys were conducted at the very end of their vacation (Lee, 2003; Rylander, Propst \& McMurtry, 1995). The total expenditure for a travel party was comprised of lodging expenditure at a minimum, followed by the other spending categories (food and beverages, car rental, gasoline, activities and entertainment, and shopping) as they occurred in KFC only. In other words, all the participants acknowledged lodging expenditures, but not necessarily all the other expenditure categories. In addition, in order to compute the average expenditures per-day, each spending category was divided by the party's length of stay.

Finally, the participants were asked to provide current trip-related information: the number of days spent in Kissimmee-St Cloud (length of stay), the total number of people included in the travel party, and the type of accommodation (hotel/motel/suite or timeshare). In addition, the survey included a question regarding the number of previous overnight visits to Kissimmee-St Cloud. Since the current study adopts the behavioral approach to loyalty, and in order to compare between loyalty segments, this variable was transformed into a categorical variable. Previous related studies usually divide visitors into two categories: first-time versus repeat visitors - two or more visitations (e.g., Anwar \& Sohail, 2004; Kozak et al., 2004; Oppermann, 1996; Petrick, 2004a). Nevertheless, this approach has been criticized by Oppermann (1999), who argued that such studies have "taken the very superficial route of only identifying repeat and first-time visitors rather than discriminating among the various repeat visitors" (p. 56). Indeed, some contemporary studies have begun to consider different levels of behavioral loyalty (e.g., Oppermann, 2000; Petrick, 2004b; Wang, 2004). Thus, the current study 
adopts Oppermann's (1999) proposal to differentiate between three loyalty segments: no previous visit, one previous visit, and multiple visits (two visits or more). The observations for each segment were $1,884,775$, and 1,642 , respectively.

Sets of One-Way ANOVA and Chi Square Test of Association analyses will be utilized in order to examine the differences between the segments with regards to socio-demographic characteristics, trip-related variables, and expenditure patterns during the visitors' last stay in Kissimmee-St Cloud. In the cases where significant results have been obtained in an ANOVA, a Scheffe post hoc test was used to determine where differences lie between the three segments.

\section{FINDINGS}

\section{Socio-Demographic characteristics}

The first comparison was conducted in order to investigate whether or not the three loyalty segments differed in their socio-demographic characteristics (see Table 1). Regarding the origin of the participants, the percentage of US visitors exceeded that of the inbound tourists in all loyalty segments. However, the segments were significantly different $\left(\chi^{2}{ }_{2}=500.312, \mathrm{P}<0.001\right)$ in their proportions of US vs. inbound tourists: first-timers were characterized by a higher proportion of inbound tourists (45.4\%), in comparison to those with one previous visit (20.9\%) and those with multiple visits $(12.2 \%)$.

Another significant difference $\left(F_{2,4297}=187.530, \mathrm{p}<0.001\right)$ was found between the segments, based on the average age. The lowest average age was found among first timers (37.78), followed by those with one previous visit (41.66) and those with multiple visits (45.24). A Chi Square test of association confirmed that the difference in the distribution of age groups between the segments was significant $\left(\chi^{2} 10=356.292, \mathrm{P}<0.001\right)$. Among the first timers, $62.4 \%$ 
were between the ages of 18 and $39 ; 67.1 \%$ of those with one previous visit were between the ages of 30-49; while $62.0 \%$ of those with multiple visits were aged 40 or above.

Finally, a chi square test of association was conducted to evaluate whether the proportions of different income levels varied between the loyalty segments. It was found that the annual income was indeed statistically significant in relation to the loyalty segment each respondent belonged to $\left(\chi^{2} 20=426.622, \mathrm{P}<0.001\right)$. The proportion of low income respondents $(<\$ 60,000)$ was higher among first time visitors than among the two repeater categories, while the proportion of the higher income respondents $(>\$ 60,000)$ was higher among those who had one or more previous visits.

\section{ENTER TABLE 1 HERE}

\section{Trip-Related Variables}

The trip-related variables examined in the study were length of stay, party size and type of accommodation. As can be seen from Table 2, the results of the ANOVA test found a significant difference between the loyalty segments based on their average length-of-stay $\left(\mathrm{F}_{2,4298}=5.342, \mathrm{p}<0.01\right)$. However, the Scheffe post hoc test indicated no significant difference in the average length of stay between first-time visitors $(M=5.16)$ and those with multiple visits $(M=4.97)$. The only significant difference that was found was between first timers and those with one previous visit $(\mathrm{M}=4.74)$, where the former showed a higher average length of stay. The finding that those with one previous visit were not significantly distinguished from those with multiple visits in their average length of stay point to a loose and limited link between loyalty and length of stay. 
The next trip-related variable examined was the party size. Although the ANOVA test found a significant difference between the loyalty segments based on the party size $\left(\mathrm{F}_{2,4297}=3.083, \mathrm{p}<0.05\right)$, the Scheffe post hoc test revealed a significant difference only between those with one previous visit $(M=2.90)$ and those with multiple visits $(M=3.07)$. No significant difference in party size was found between the first timers $(M=3.00)$ and the other two loyalty segments. Therefore, first time and repeat visitors were not statistically distinguished from each other in term of their party size. Finally, the chi square test of association found no significant link between the type of accommodation and any of the loyalty segment $\left(\chi^{2}{ }_{2}=4.642, \mathrm{P}>0.05\right)$.

\section{ENTER TABLE 2 HERE}

\section{Tourist Spending}

The comparisons between the loyalty segments based on their average travel expenditures are presented in Table 3 (the white lines represent expenditures per-trip and the shaded lines represent expenditures per-day). A significant difference between the loyalty segments was found in each of the expenditure categories, in terms of both per-trip and per-day spending. In terms of total expenditure per-trip, first timers spent an average of $\$ 965.52$ per trip, which was significantly higher than the other loyalty segments. However, no statistically significant difference was found between those with one previous visit $(M=\$ 778.78)$ and those with multiple visits $(M=\$ 842.86)$. A similar pattern was found in the categories of food and restaurant meals, lodging, and car rental, where first timers spent significantly more per-trip than the two repeater segments. Nevertheless, in the other expenditure categories - gasoline, activities and entertainment, and shopping - those with multiple visits spent significantly more per-trip 
than both first timers and those with one previous visit. In the case of gasoline expenditures only, those with one previous visit spent more than first timers.

Although, as was shown in the previous section, the difference in length of stay between the loyalty segments was only marginal, a comparison was also conducted on the basis of expenditure per-day in order to neutralize the impact of the length of stay on the total expenditures. As can be seen in Table 3, a very similar picture to the expenditures per-trip emerged when considering expenditures per-day, the most important detail being that first timers spent more per-day $(M=\$ 186.29)$, in total, than both those with one previous visit $(M=\$ 163.88)$ and those with multiple visits $(\mathrm{M}=\$ 172.03)$. Regarding the spending categories, the first timers spent significantly more per-day than both repeater segments on lodging, and more than only those with multiple visits on car rental and food and restaurant meals. However, in comparison to the first timers and those with one previous visit, those with multiple visits spent significantly more per-day on shopping, activities and entertainment, and gasoline.

\section{ENTER TABLE 3 HERE}

\section{CONCLUSIONS AND IMPLICATIONS}

The aim of the study was to contribute to the literature on the relationship between destination loyalty and travel expenditures, using the tourism destination of Kissimmee/St. Cloud as a case study. The question of whether or not loyal customers/visitors do indeed spend more than non- or less-loyal customers/visitors is the subject of an ongoing debate in contemporary marketing literature (e.g., Helgesen, 2006; Miller \& Grazer, 2003; Petrick 2004; Reinartz \& Kumar, 2000, 2002). Therefore, the current study can be seen as another step in clarifying the 
value of loyal visitors, as it is realized in terms of tourist spending. As recommended by Oppermann (2000a, 2000b) and Pritchard et al. (1992), the study used the behavioral approach to loyalty, whereby it is determined by the number of prior visits to a destination. In line with this approach, the tourists were divided into three categories: no previous visits, one previous visit and multiple visits (see Oppermann, 1999). The comparison between the segments was based on total per-trip and per-day expenditures, as well as expenditures across different spending categories.

The results of the study clearly indicate that first-timers (those with no previous visits) are a viable and prominent segment for Kissimmee-St Cloud. It was found that they spend significantly more both regarding per-trip and per-day total expenditures, than the two repeater segments. It should be noted that the differences between the segments regarding length of stay and party size are limited, thus the findings point to fundamentally different spending trends between the segments. The study's results are consistent with some earlier studies (Jang et al., 2004; Oppermann, 1996, 1997; Petrick, 2004) which indicated that less-loyal visitors (in this context - first timers) spend more at the destination. It also strengthened the call of scholars such as Reinartz and Kumar (2000, 2002) and Henry (2000) for caution in automatically assuming that loyal customers are willing to pay more for a brand and/or that they are less price-sensitive. Nevertheless, the findings are contradictory with those of Wang (2004), who found that repeat visitors are bigger spenders and So and Morrison (2004) who found no spending differences based on the tourists' number of previous visits. At the very least, this study provides evidence to the fact that the clear preference on the part of many tourism destinations to allocate marketing resources to loyal visitors (Fyall et al., 2003; Lehto et al., 2004), often at the expense of attracting first timers, should be reconsidered and reevaluated. 
Nonetheless, the study went one step further in taking into account not only the total expenditures, but the different spending categories, as well. Taking this into consideration, a more complicated picture emerged regarding the visitors' spending patterns. While first timers spend more on food and restaurant meals, lodging, and car rental, the more loyal visitors spend more on gasoline, activities and entertainment, and shopping. Since the study examined expenditures at Kissimmee/St Cloud only, these findings portrayed different tourist behaviors at the destination for first timers and repeaters. First timers spend more on lodging and restaurants, seemingly due to a lack of knowledge regarding the destination, which may often place them in an inferior bargaining position. The more loyal visitors, on the other hand, seem to be able to get better deals on lodging and find cheaper places to dine, once their familiarity with and orientation at the destination have improved. First timers also spend more on car rentals at the destination, which may stem from their concern about driving by themselves to the still unfamiliar destination; more loyal visitors, on the other hand, seem more confident about reaching the destination by themselves.

On the other hand, the more loyal segments have higher expenditures at the destination in gasoline, activities and entertainment, and shopping, all of which indicate that they prefer to focus more on activities at Kissimmee/St Cloud, compared to the first timers who tend to focus more on activities outside Kissimmee/St Cloud. Bearing in mind the context of Central Florida, it is reasonable to assume, in light of these findings, that while first timers spend more on activities in iconic attractions, such as Disneyworld or Universal Studios (which are located outside Kissimmee/St Cloud), repeat visitors, after experiencing the traditional attractions, prefer to spend more time dining, shopping and on local attractions in Kissimmee/St Cloud. These findings are consistent with some earlier studies (Anwar \& Sohail, 2004; Kemperman et al., 
2004; Lau \& McKercher, 2004; Oppermann, 1996, 1997; Wang, 2004), which indicated that first timers are more likely to be active, visiting mega-attractions and touring the area, while repeat visitors tend to revolve within a more limited geographical area, and to engage in more relaxing experiences, such as shopping and dining.

The study provides important marketing implications for the tourism destination of Kissimmee/St Cloud, the most important one being that the less loyal visitors' segment should not be neglected. In order to better identify first timer segments, based on the examination of the socio-demographics characteristics of the segments, it should be noted that that they are younger, with a lower annual income and have a higher proportion of inbound tourists, compared to the repeater segments. Nevertheless, in light of the segment differences in the distribution of expenditures across the spending categories, different hospitality sectors should consider different marketing strategies regarding loyal visitors. More specifically, in the case of Kissimmee/St Cloud, local attractions and shopping facilities should focus specifically on the loyal visitor segment, since they are more likely to spend more on these activities.

The current study is not without limitations. First of all, as was noted before, spending is only one factor in determining profitability, thus it is plausible that although they are characterized by higher spending, first timers are more costly in terms of marketing and/or service efforts. Thus, future research should include other profitability indicators as well. Secondly, Kissimmee/St Cloud is a distinguished destination, characterized by icon attractions located outside its boundaries. Therefore, the results should be generalized with caution, as external validity seems to set some limitations to the study - other destinations should be examined in future studies. Thirdly, the study relies on the respondents' report on their expenditures, which might not fully reflect their actual spending in Kissimmee-St Cloud. 
However, the data collection occurred at the destination at the end of the respondents' vacation, thus significantly minimized recall bias and enhances the internal validity of the findings. It should be noted also that survey was conducted over period of 12 months, thus increases the reliability of the reported expenditures. Finally, in order to generate more meaningful and specific implications, more information is needed on the characteristics of the various spending segments, especially concerning the information sources used prior to the trip and the prominent decision makers in the travel party. Nevertheless, the study can assist local decision makers in marketing planning, and contributes to the understanding of travel expenditures across spending segments, while providing further confirmation with regards to the overestimation of loyalty in tourism marketing.

\section{REFERENCES}

Answar, S.A., and Sohail, M.S. (2004). Festival tourism in the United Arab Emirates: first-time versus repeat visitor perceptions. Journal of Vacation Marketing, 10(2), 161-170.

Backman, S. J., \& Crompton, J. L. (1991). The Usefulness of Selected Variables for Predicting Activity Loyalty. Leisure Sciences, 13(3), 205-220.

Bai, B., Buxton, M., Sammons, G., and Shoemaker, S. (2006). Restaurant customer loyalty: a qualitative assessment of niche brands. FIU Hospitality and Tourism Review, 24(1), 10-20.

Bolton, R.N., Kannan, P.K., and Bramlett, M.D. (2000). Implications of loyalty program membership and service experiences for customer retention and value. Journal of the Academy of Marketing Science, 28(1), 95-108.

Bowen, J.T., and Shoemaker, S. (2003). Loyalty: a strategic commitment. Cornell Hotel and Restaurant Administration Quarterly, 44(5/6), 31-46. 
Bush, A.J., and Hair, J.F. (1985). An assessment of the mall intercept as a data collection method. Journal of Marketing Research, 22(2), 158-167.

Chang, J.C. (2006). Customer satisfaction with tour leaders' performance: a study of Taiwan's package tours. Asia Pacific Journal of Tourism Research, 11(1), 97-116.

Chen, J.S., and Gursoy, D. (2001). An investigation of tourists' destination loyalty and preferences. International Journal of Contemporary Hospitality Management, 13(2), 7985.

Croes, R.R., and Severt, D.E. (2007). Evaluating short-term tourism economic effects in confined economies - conceptual and empirical considerations. Tourism Economics, 13(2), 289-307.

Darnell, A.C., and Johnson, P.S. (2001). Repeat visits to attractions: a preliminary economic analysis. Tourism Management, 22(2), 119-126.

Dick, A.S., and Basu, K. (1994). Customer loyalty: toward an integrated conceptual framework. Journal of the Academy of Marketing Science, 22(2), 99-113.

Dowling, G.R., and Uncles, M. (1997). Do customer loyalty programs really work? Sloan Management Review, 38(4), 71-82.

Fakeye, P. C., \& Crompton, J. L. (1991). Image differences between prospective, first-time, and repeat visitors to the lower Rio Grande Valley. Journal of Travel Research, 30(2), 10-16.

Finn, A., and Erdem, T. (1995). The economic impact of a mega-multi-mall estimation issues in the case of West Edmonton Mall. Tourism Management, 16(5), 367-373.

Fyall, A., Callod, C., and Edwards, B. (2003). Relationship marketing: the challenge for destinations. Annals of Tourism Research, 30(3), 644-659. 
Gitelson, R. J., \& Crompton, J. L. (1984). Insights into the Repeat Vacation Phenomenon. Annals of Tourism Research, 11(2), 199-217.

Hallowell, R. (1996). The relationships of customer satisfaction, customer loyalty, and profitability: an empirical study. International Journal of Service Industry Management, 7(4), 27-42.

Han, H., and Back, K.J. (2006). Investigating the effects of consumption emotions on customer satisfaction and repeat visit intentions in the lodging industry. Journal of Hospitality and Leisure Marketing, 15(3), 5-30.

Helgessen, Ø. (2006). Are loyal customers profitable? Customer satisfaction, customer (action) loyalty and customer profitability at the individual level. Journal of Marketing Management, 22(3), 245-266.

Henry, C.D. (2000). Is customer loyalty a pernicious myth? Business Horizons, 43(4), 13-16.

Heskett, J.L., Jones, T.O., Loveman, G.W., Sasser, W.E., and Schlesinger, L.A. (1994). Putting the service-profit chain to work. Harvard Business Review, 72(2), 164-170.

Hughes, A. M. (1995). Making a database pay off using Recency, Frequency and Monetary analysis. Journal of Database Marketing, 3(1), 77-89.

Jacoby, J., \& Chestnut, R. W. (1978). Brand Loyalty: Measurement and Management. New York: John Wiley.

Jang, D., and Mattila, A.S. (2005). An examination of restaurant loyalty programs: what kinds of rewards do customers prefer? International Journal of Contemporary Hospitality Management, 17(5), 402-408. 
Jang, S.C., Bai, B., Hong, G.S., and O’Leary, J.T. (2004), Understanding travel expenditure patterns: a study of Japanese pleasure travelers to the United States by income level. Tourism Management, 25(3), 331-341.

Kandampully, J., and Hu, H.H. (2007). Do hoteliers need to manage image to retain loyal customers? International Journal of Contemporary Hospitality Management, 19(6), 435443.

Kemperman, A.D.A.M., Joh, C.H., and Timmermans, H.J.P. (2004). Comparing first-time and repeat visitors' activity patterns in a tourism environment. In G.I. Crouch, R.R. Perdue, H.J.P. Timmermans, and M. Uysal (Eds.), Consumer psychology of tourism, hospitality and leisure (Vol. 3). CAB International.

Kim, H., and Jamal, T. (2007). Touristic quest for existential authenticity. Annals of Tourism Research, 34(1), 181-201.

Kim, H., Borges, M.C., and Chon, J. (2006). Impacts of environmental values on tourism motivation: the case of FICA, Brazil. Tourism Management, 27(5), 957-967.

Kissimmee-St Cloud Convention and Visitors Bureau. (2006). Facts and Stats. Retrieved January 20, 2008, from http://media.floridakiss.com/facts/index.php

Klophaus, R. (2005). Frequent flyer programs for European low-cost airlines: prospects, risks and implementation guidelines. Journal of Air Transport Management, 11(5), 348-353.

Kozak, M. (2006). A content analysis of repeaters' self-perceptions of tourist destinations. Tourism Review, 61(1), 21-25.

Kozak, M., Nigné, E. \& Andreu, L. (2004). Satisfaction and destination loyalty: a comparison between non-repeat and repeat tourists. Journal of Quality Assurance in hospitality and Tourism, 5(1), 43-59. 
Kundampully, J., and Suhartano, D. (2000). Customer loyalty in the hotel industry: the role of customer satisfaction and image. International Journal of Contemporary Hospitality Management, 12(6), 346-351.

Lau, A.L.S., and McKercher, B. (2004). Exploration versus acquisition: a comparison of firsttime and repeat visitors. Journal of Travel Research, 42(3), 279-285.

Lee, H.C. (2003). Estimating recreational boater expenditures on trips and boating use in a wave survey. Leisure Sciences, 25(4), 381-397.

Lee, J., Graefe, A.R., and Burns, R.C. (2007). Examining the antecedents of destination loyalty in a forest setting. Leisure Sciences, 29(5), 463-481.

Lehto, X.Y., O’Leary, J.T., and Morrison, A.M. (2004). The effect of prior experience on vacation behavior. Annals of Tourism Research, 31(4), 801-818.

Levy, S.E., and Hassay, D.N. (2005). Visitor communities. Journal of Hospitality and Leisure Marketing, 12(4), 57-72.

Litvin, S.W., and Kar, G.H. (2001). E-surveying for tourism research: legitimate tool or a researcher's fantasy? Journal of Travel Research, 39(3), 308-314.

Loveman, G.W. (1998). Employee satisfaction, customer loyalty, and financial performance: an empirical examination of the service profit chain in retail banking. Journal of Service Research, 1(1), 18-31.

Mattila, A.S. (2006a). How affective commitment boosts guest loyalty (and promotes frequent guest programs). Cornell Hotel and Restaurant Administration Quarterly, 47(2), 174-181. Mattila, A.S. (2006b). The impact of affective commitment and hotel type in influencing guests' share of wallet. Journal of Hospitality and Leisure Marketing, 15(4), 55-68. 
Matzler, K., Füller, J., and Faullant, R. (2007). Customer satisfaction and loyalty to Alpine ski resorts: the moderating effect of lifestyle, spending and customers' skiing skills. International Journal of Tourism Research, 9(6), 409-421.

Miller, A.R., and Grazer, W.F. (2003). Complaint behavior as a factor in cruise line losses: a analysis of brand loyalty. Journal of Travel and Tourism Marketing, 15(1), 77-91.

Miller, K.W., Wilder, L.B., Stillman, F.A., Becker, D.M. (1997). The feasibility of a streetintercept survey method in an African-American community. American Journal of Public Health, 87(4), 655-658.

Mok, C., and Iverson, T.J. (2000). Expenditure-based segmentation: Taiwanese tourists to Guam. Tourism Management, 21(3), 299-305.

Niininen, O., Szivas, E., and Riley, M. (2004). Destination loyalty and repeat behaviour: an application of optimum stimulation measurement. International Journal of Tourism Research, 6(6), 439-447.

Niraj, R., Gupta, M., and Narasimhan, C. (2001). Customer profitability in a supply chain. Journal of Marketing, 65(3), 1-16.

Oliver, R.L. (1999). Whence consumer loyalty? Journal of Marketing, 63(4), 33-44.

Oppermann, M. (1996). Visitation of tourism attractions and tourist expenditure patterns - repeat versus first-time visitors. Asia Pacific Journal of Tourism Research, 1(1), 61-68.

Oppermann, M. (1997). First-time and repeat visitors to New Zealand. Tourism Management, $18(3), 177-181$

Oppermann, M. (1999). Predicting destination choice - a discussion of destination loyalty. Journal of Vacation Marketing, 5(1), 51-65.

Oppermann, M. (2000a). Tourism destination loyalty. Journal of Travel Research, 39(1), 78-84. 
Oppermann, M. (2000b). Where psychology and geography interface in tourism research and theory. In A.G. Woodside, G.I. Crouch, J.A. Mazanac, M. Oppermann, \& M.Y. Sakai (Eds.), Consumer psychology of tourism, hospitality and leisure (pp.19-37). Wallingford, UK: CABI Publishing.

Paas, L.J. (1998). Mokken scaling characteristic sets and acquisition patterns of durable- and financial products. Journal of Economic Psychology, 19(3), 353-376.

Palmer, R., and Mahoney, E. (2005). Winners and losers: segmenting a casino loyalty programme. International Gambling Studies, 5(2), 271-287.

Pearce, D.G., and Schott, C. (2005). Tourism distribution channels: the visitors' perspective. Journal of Travel Research, 44(1), 50-63.

Petrick, J.F. (2004a). Reoperationalizing the loyalty framework. Tourism and Hospitality Research, 5(3), 199-212.

Petrick, J.F. (2004b). Are loyal visitors desired visitors? Tourism Management, 25(4), 463-470.

Petrick, J.F. (2005). Reoperationalizing the loyalty framework. Tourism and Hospitality Research, 5(3), 199-212.

Petrick, J.F., and Sirakaya, E. (2004). Segmentation cruisers by loyalty. Annals of Tourism Research, 31(2), 472-475.

Pfeifer, P.E., Haskins, M.E., and Conroy, R.M. (2005). Customer lifetime value, customer profitability, and the treatment of acquisition. Journal of Managerial Issues, 17(1), 11-25.

Pike, S. (2007). Repeat visitors - an exploratory investigation of responses by regional tourism organizations. Journal of Travel and Tourism Research, 7(1), 1-13.

Pritchard, M., Howard, D. R., and Havitz, M. E. (1992). Loyalty Measurement: A Critical Examination and Theoretical Extension. Leisure Sciences, 14, 155-164. 
Ranaweera, C. (2007). Are satisfied long-term customers more profitable? Evidence from the telecommunication sector. Journal of Targeting, Measurement and Analysis for Marketing, 15(2), 113-120.

Ravald, A., and Grönroos, C. (1996). The value concept and relationship marketing. European Journal of Marketing, 30(2), 19-30.

Reichheld, F.F. (1996). The loyalty effect. Boston, Massachusetts: Harvard Business School Press.

Reichheld, F.F., and Sasser, Jr., W.R. (1990). Zero defections: quality comes to services. Harvard Business Review, 68(5), 105-111.

Reinartz, W.J., and Kumar, V. (2000). On the profitability of long-life customers in a noncontractual setting: an empirical investigation and implications for marketing. Journal of Marketing, 64(4), 17-35.

Reinartz, W.J., and Kumar, V. (2002). The mismanagement of customer loyalty. Harvard Business Review, 80(7), 86-94.

Rittichainuwat, B.N., Qu, H., and Mongkhonvanit, C. (2006). A study of the impact of travel inhibitors on the likelihood of travelers' revisiting Thailand. Journal of Travel and Tourism Marketing, 21(1), 77-87.

Rylander, R.G., Propst, D.B., and McMurtry, T.R. (1995). Nonresponse and recall biases in a survey of traveler spending. Journal of Travel Research, 33(4), 39-45.

Shoemaker, S., and Lewis, R.C. (1999). Customer loyalty: the future of hospitality marketing. International Journal of Hospitality Management, 18(4), 345-370.

Sim, J., Mak, B., and Jones, D. (2006). A model of customer satisfaction and retention for hotels. Journal of Quality Assurance in Hospitality and Tourism, 7(3), 1-23. 
Skogland, I., and Siguaw, J.A. (2004). Are your satisfied customers loyal? Cornell Hotel and Restaurant Administration Quarterly, 45(3), 221-234.

So, S., and Morrison, A.M. (2004). The repeat travel market for Taiwan: a multi-stage segmentation approach. Asia Pacific Journal of Tourism Research, 9(1), 71-87.

Soteriades, M.D., and Arvanitis, S.E. (2006). Expenditure patterns by travel party size: British and German tourists on Crete, Greece. Anatolia: An International Journal of Tourism and Hospitality Research, 17(2), 169-178.

Srinivasan, S.S., Anderson, R., and Ponnavolu, K. (2002). Customer loyalty in e-commerce: an exploration of its antecedents and consequences. Journal of Retailing, 78(1), 41-50.

Stauss, B., Schmidt, M., and Schoeler, A. (2005). Customer frustration in loyalty programs. International Journal of Service Industry Management, 16(3), 229-252.

Tepeci, M. (1999). Increasing brand loyalty in the hospitality industry. International Journal of Contemporary Hospitality Management, 11(5), 223-229.

Tiefenbacher, J.P., Day, F.A., and Walton, J.A. (2000). Attributes of repeat visitors to small tourist-oriented communities. The Social Science Journal, 37(2), 299-308.

Wang, D. (2004). Tourist behaviour and repeat visitation to Hong Kong. Tourism Geographies, 6(1), 99-118.

Wang, Y., Rompf, P., Severt, D., and Peerapatdit, N. (2006). Examining and identifying the determinants of travel expenditure patterns. International Journal of Tourism Research, $8(5), 333-346$.

Wickens, E. (2004). Repeat visitor - host encounters: a case study from Greece. Tourism: An International Interdisciplinary Journal, 52(2), 143-150. 
Wirtz, J., Mattila A.S., and Lwin, M.O. (2007). How effective are loyalty reward programs in driving share of wallet? Journal of Service Research, 9(4), 327-334.

Yoon, Y., and Uysal, M. (2005). An examination of the effects of motivation and satisfaction on destination loyalty: a structural model. Tourism Management, 26(1), 45-56.

Yüksel, A., and Yüksel, F. (2007). Shopping risk perceptions: effects on tourists' emotions, satisfaction and expressed loyalty intentions. Tourism Management, 28(3), 703-713. 
Table 1: Socio-demographic variables, per loyalty segment

\begin{tabular}{|c|c|c|c|c|c|c|}
\hline Variable & $\begin{array}{c}\text { Total } \\
\text { Sample } \\
(\mathrm{N}=4,301)\end{array}$ & $\begin{array}{c}\text { No } \\
\text { Previous } \\
\text { Visits } \\
(\mathrm{N}=1,884) \\
\end{array}$ & $\begin{array}{c}\text { One } \\
\text { Previous } \\
\text { Visit } \\
(\mathrm{N}=775)\end{array}$ & $\begin{array}{c}\text { Multiple } \\
\text { Visits } \\
(\mathrm{N}=1,642)\end{array}$ & $\begin{array}{l}\text { F or } x^{2} \\
\text { Value }\end{array}$ & Sig. \\
\hline Country of origin & & & & & $X^{2}=500.312$ & $<.001$ \\
\hline USA & $71.7 \%$ & $54.6 \%$ & $79.1 \%$ & $87.8 \%$ & & \\
\hline Other than USA & $28.3 \%$ & $45.4 \%$ & $20.9 \%$ & $12.2 \%$ & & \\
\hline Age (mean) & 41.33 & $37.78^{a}$ & $41.66^{b}$ & $45.24^{c}$ & $F=187.530$ & $<.001$ \\
\hline $18-29$ & $16.0 \%$ & $22.0 \%$ & $12.8 \%$ & $10.7 \%$ & $x^{2}=356.292$ & $<.001$ \\
\hline $30-39$ & $34.3 \%$ & $40.4 \%$ & $34.1 \%$ & $27.3 \%$ & & \\
\hline $40-49$ & $27.2 \%$ & $24.6 \%$ & $33.0 \%$ & $27.4 \%$ & & \\
\hline $50-59$ & $13.3 \%$ & $9.6 \%$ & $13.2 \%$ & $17.5 \%$ & & \\
\hline $60-69$ & $7.9 \%$ & $3.0 \%$ & $5.8 \%$ & $14.6 \%$ & & \\
\hline 70 or above & $1.4 \%$ & $0.5 \%$ & $1.2 \%$ & $2.5 \%$ & & \\
\hline Annual income & & & & & $X^{2}=426.622$ & $<.001$ \\
\hline$<\$ 20,000$ & $2.4 \%$ & $4.2 \%$ & $0.9 \%$ & $1.1 \%$ & & \\
\hline$\$ 20,001-\$ 29,999$ & $5.7 \%$ & $8.8 \%$ & $3.6 \%$ & $3.3 \%$ & & \\
\hline$\$ 30,000-\$ 39,999$ & $13.0 \%$ & $18.3 \%$ & $10.8 \%$ & $7.9 \%$ & & \\
\hline$\$ 40,000-\$ 49,999$ & $13.1 \%$ & $16.8 \%$ & $12.6 \%$ & $9.1 \%$ & & \\
\hline$\$ 50,000-\$ 59,999$ & $10.1 \%$ & $11.8 \%$ & $7.9 \%$ & $9.2 \%$ & & \\
\hline$\$ 60,000-\$ 69,999$ & $9.5 \%$ & $9.2 \%$ & $8.4 \%$ & $10.4 \%$ & & \\
\hline$\$ 70,000-\$ 79,999$ & $8.1 \%$ & $6.2 \%$ & $8.3 \%$ & $10.4 \%$ & & \\
\hline$\$ 80,000-\$ 89,999$ & $7.3 \%$ & $5.6 \%$ & $9.2 \%$ & $8.2 \%$ & & \\
\hline$\$ 90,000-\$ 99,999$ & $6.4 \%$ & $3.8 \%$ & $9.0 \%$ & $8.1 \%$ & & \\
\hline$\$ 100,000$ or above & $12.2 \%$ & $6.1 \%$ & $16.4 \%$ & $17.3 \%$ & & \\
\hline Refused & $12.1 \%$ & $9.2 \%$ & $12.9 \%$ & $15.1 \%$ & & \\
\hline
\end{tabular}

Note: $\mathrm{F}$ and significant level are presented for the initial One-Way ANOVA analysis. Significant differences in the means between pairs of the three loyalty segments (no previous visits, one previous visit, multiple visits) based on the Scheffe test are indicated by the letters $a, b$ or $c$. Pairs of means that do not have the same letter are significantly different whereas those pairs of means that have the same superscript are not significantly different. $\chi^{2}$ and significant level are presented for the chi square test of association. 
Table 2: Trip-related variables, per loyalty segment

\begin{tabular}{lcccccc}
\hline & $\begin{array}{c}\text { Total Sample } \\
(\mathrm{N}=4,301)\end{array}$ & $\begin{array}{c}\text { No Previous } \\
\text { Visits } \\
(\mathrm{N}=1,884)\end{array}$ & $\begin{array}{c}\text { One Previous } \\
\text { Visit } \\
(\mathrm{N}=775)\end{array}$ & $\begin{array}{c}\text { Multiple Visits } \\
(\mathrm{N}=1,642)\end{array}$ & $\begin{array}{c}\mathrm{F} \text { or } \mathrm{X}^{2} \\
\text { Value }\end{array}$ & Sig. \\
\hline Length of stay & 5.01 & $5.16^{\mathrm{a}}$ & $4.74^{\mathrm{b}}$ & $4.97^{\mathrm{ab}}$ & $\mathrm{F}=5.342$ & .005 \\
Party size & 3.01 & $3.00^{\mathrm{ab}}$ & $2.90^{\mathrm{a}}$ & $3.07^{\mathrm{b}}$ & $\mathrm{F}=3.083$ & .046 \\
Lodging & & & & & $\mathrm{X}^{2}=4.642$ & .098 \\
$\quad$ Hotel/Motel & $78.2 \%$ & $79.7 \%$ & $78.1 \%$ & $76.7 \%$ & & \\
$\quad$ Timeshare & $21.8 \%$ & $20.3 \%$ & $21.9 \%$ & $23.3 \%$ & & \\
\hline
\end{tabular}

1. Including short-term rental

Note: $\mathrm{F}$ and significant level are presented for the initial One-Way ANOVA analysis. Significant differences in the means between pairs of the three loyalty segments (no previous visits, one previous visit, multiple visits) based on the Scheffe test are indicated by letters $a, b$ or $c$. Pairs of means that do not have the same letter are significantly different whereas those pairs of means that have the same superscript are not significantly different. $x^{2}$ and significant level are presented for the chi square test of association. 
Table 3: Expenditures, per loyalty segment

\begin{tabular}{|c|c|c|c|c|c|c|}
\hline Expenditure Variable (\$Avg.) & $\begin{array}{c}\text { Total } \\
\text { Sample } \\
(\mathrm{N}=4,301)\end{array}$ & $\begin{array}{c}\text { No } \\
\text { Previous } \\
\text { Visits } \\
(\mathrm{N}=1,884)\end{array}$ & $\begin{array}{c}\text { One } \\
\text { Previous } \\
\text { Visit } \\
(\mathrm{N}=775)\end{array}$ & $\begin{array}{c}\text { Multiple } \\
\text { Visits } \\
(\mathrm{N}=1,642)\end{array}$ & F Value & Sig. \\
\hline Total expenditures per-trip & $\begin{array}{l}885.04 \\
(100 \%)\end{array}$ & $\begin{array}{c}965.52^{a} \\
(100 \%)\end{array}$ & $\begin{array}{l}778.78^{b} \\
(100 \%)\end{array}$ & $\begin{array}{l}842.86^{b} \\
(100 \%)\end{array}$ & 24.794 & $<.001$ \\
\hline Total expenditures per-day & $\begin{array}{l}176.81 \\
(100 \%)\end{array}$ & $\begin{array}{l}186.29^{a} \\
(100 \%)\end{array}$ & $\begin{array}{l}163.88^{b} \\
(100 \%)\end{array}$ & $\begin{array}{l}172.03^{b} \\
(100 \%)\end{array}$ & 16.075 & $<.001$ \\
\hline $\begin{array}{l}\text { Food and restaurant meals } \\
\text { per-trip }\end{array}$ & $\begin{array}{c}256.14 \\
(28.9 \%)\end{array}$ & $\begin{array}{l}277.73^{a} \\
(28.8 \%)\end{array}$ & $\begin{array}{l}239.35^{b} \\
(30.7 \%)\end{array}$ & $\begin{array}{l}239.29^{b} \\
(28.4 \%)\end{array}$ & 14.960 & $<.001$ \\
\hline $\begin{array}{l}\text { Food and restaurant meals } \\
\text { per-day }\end{array}$ & $\begin{array}{c}53.22 \\
(30.1 \%)\end{array}$ & $\begin{array}{c}55.63^{a} \\
(29.9 \%)\end{array}$ & $\begin{array}{l}51.78^{a b} \\
(31.6 \%)\end{array}$ & $\begin{array}{l}51.12^{\mathrm{b}} \\
(29.7 \%)\end{array}$ & 6.339 & .002 \\
\hline Lodging per-trip & $\begin{array}{l}487.33 \\
(55.1 \%)\end{array}$ & $\begin{array}{l}567.88^{a} \\
(58.8 \%)\end{array}$ & $\begin{array}{l}421.90^{\mathrm{b}} \\
(54.2 \%)\end{array}$ & $\begin{array}{l}425.80^{\mathrm{b}} \\
(50.5 \%)\end{array}$ & 59.027 & $<.001$ \\
\hline Lodging per-day & $\begin{array}{c}97.53 \\
(55.2 \%)\end{array}$ & $\begin{array}{c}110.45^{a} \\
(59.3 \%)\end{array}$ & $\begin{array}{c}90.72^{b} \\
(55.4 \%)\end{array}$ & $\begin{array}{c}85.91^{b} \\
(49.9 \%)\end{array}$ & 59.161 & $<.001$ \\
\hline Car rental per-trip & $\begin{array}{c}10.42 \\
(1.2 \%)\end{array}$ & $\begin{array}{l}17.14^{a} \\
(1.8 \%)\end{array}$ & $\begin{array}{c}8.54^{b} \\
(1.1 \%)\end{array}$ & $\begin{array}{c}3.60^{b} \\
(0.4 \%)\end{array}$ & 19.737 & $<.001$ \\
\hline Car rental per-day & $\begin{array}{c}2.23 \\
(1.3 \%)\end{array}$ & $\begin{array}{c}3.62^{a} \\
(1.9 \%)\end{array}$ & $\begin{array}{l}2.17^{\mathrm{ab}} \\
(1.3 \%)\end{array}$ & $\begin{array}{c}0.65^{b} \\
(0.4 \%)\end{array}$ & 15.727 & $<.001$ \\
\hline Gasoline per-trip & $\begin{array}{l}19.98 \\
(2.3 \%)\end{array}$ & $\begin{array}{l}13.75^{\mathrm{a}} \\
(1.4 \%)\end{array}$ & $\begin{array}{l}18.75^{b} \\
(2.4 \%)\end{array}$ & $\begin{array}{l}27.71^{\mathrm{c}} \\
(3.3 \%)\end{array}$ & 79.602 & $<.001$ \\
\hline Gasoline per-day & $\begin{array}{c}3.92 \\
(2.2 \%)\end{array}$ & $\begin{array}{c}2.31^{\mathrm{a}} \\
(1.2 \%)\end{array}$ & $\begin{array}{l}3.55^{\mathrm{b}} \\
(2.2 \%)\end{array}$ & $\begin{array}{l}5.93^{c} \\
(3.4 \%)\end{array}$ & 124.461 & $<.001$ \\
\hline $\begin{array}{l}\text { Activities and entertainment } \\
\text { per-trip }\end{array}$ & $\begin{array}{l}31.53 \\
(3.6 \%)\end{array}$ & $\begin{array}{l}21.51^{a} \\
(2.2 \%)\end{array}$ & $\begin{array}{l}24.53^{a} \\
(3.1 \%)\end{array}$ & $\begin{array}{l}46.32^{b} \\
(5.5 \%)\end{array}$ & 40.633 & $<.001$ \\
\hline $\begin{array}{l}\text { Activities and entertainment } \\
\text { per-day }\end{array}$ & $\begin{array}{c}5.25 \\
(3.0 \%)\end{array}$ & $\begin{array}{c}2.93^{a} \\
(1.6 \%)\end{array}$ & $\begin{array}{c}3.85^{a} \\
(2.3 \%)\end{array}$ & $\begin{array}{c}8.58^{b} \\
(5.0 \%)\end{array}$ & 70.385 & $<.001$ \\
\hline Shopping per-trip & $\begin{array}{l}79.65 \\
(9.0 \%)\end{array}$ & $\begin{array}{l}67.51^{a} \\
(7.0 \%)\end{array}$ & $\begin{array}{l}65.71^{a} \\
(8.4 \%)\end{array}$ & $\begin{array}{l}100.14^{\mathrm{b}} \\
(11.9 \%)\end{array}$ & 21.670 & $<.001$ \\
\hline Shopping per-day & $\begin{array}{l}14.67 \\
(8.3 \%)\end{array}$ & $\begin{array}{l}11.35^{\mathrm{a}} \\
(6.1 \%)\end{array}$ & $\begin{array}{l}11.82^{\mathrm{a}} \\
(7.2 \%)\end{array}$ & $\begin{array}{c}19.84^{b} \\
(11.5 \%)\end{array}$ & 38.402 & $<.001$ \\
\hline
\end{tabular}

Note: All spending variables refer to money spent in Kissimmee-St Cloud only.

$\mathrm{F}$ and significant level are presented for the initial One-Way ANOVA analysis. Significant differences in the expenditures between pairs of the three loyalty segments (no previous visits, one previous visit, multiple visits) based on the Scheffe test are indicated by letters $a, b$ or $c$. Pairs of means that do not have the same letter are significantly different whereas those pairs of means that have the same superscript are not significantly different. Percentage may not add to $100 \%$ due to rounding. 